\title{
Schopenhauer ve Nietzsche Nihilizmi Sarkacında Dövüş Kulübü Filminin Çözümlemesi
}

\author{
Cenk Ateş* \\ Meral Serarslan**
}

\section{$\ddot{O} z e t$}

Düşünce tarihinde insanlar arasındaki yapı farkın gözetmeksizin tekil eylemlere indirgenen insan özgürlüğü problemi, Schopenhauer ve Nietzsche'yle birlikte insandan, bütünlüklü olarak kişiye evrilmiştir. İki düşünür arasındaki bu fikir birliği, özgürlüğe ulaşmada izlenecek yol bakımından farklılaşır. Görünenin ardındaki gerçekliği kavrayarak, istemeyi reddeden Schopenhauer'ın özgür ideal insanı, kaçınılmaz olarak nihilizme ulaşır. Nietzsche içinse ideal insan hâkim değerleri yok sayarak, yolunu mutlaka nihilizmden geçiren ancak bu noktayı aşarak yeni değerler yaratabilen insandır. Söz konusu görüş ayrılığı Nietzsche'de, yaşamı değerden düşüren edilgen nihilizmle; yaşamı değil; yaşamın hâkim moral anlayışıyla yorumlanmasını reddeden etken nihilizm ekseninde şekillenir. Nihilizme yönelik bu yönlü bir sinıflandırma, istemeyi susturmak anlamında Schopenhuerci nihilizmle, istemeyi susturan değerleri yıkmakla özdeşleşen, Nietzscheci etken nihilizmi iki zıt kutba yerleştirir. Schopenhauer'da nihai nokta olarak değerlendirilen 'hayır' ile, Nietzsche'de büyük bir 'evet'in ön koşulu olarak ifade edilen 'hayır', farklı amaçlara hizmet etseler de her iki filozof tarafindan olumlanır.

Nihilizm temelli bu görüş ayrılığını, yönetmenliğini David Fincher'in üstlendiği 1999 yapımı Dövüş Kulübü filminde görmek mümkündür. Farklı okumalara açık olan film, başkarakter Jack'in, üstbenin emirleri doğrultusunda yaşadığı dünyaya ilişkin usanmışlı̆̆ına anlam arayışını konu edinir. Keskin bir kapitalizm eleştirisi sunan film, hâkim değerlerin yarattığı özgürlük yanılsamasını kırarak, kişinin kendi olma serüvenini toplumsal değerlerin eylemsel düzeyde reddedilmesiyle ele alır. Özgürlüğ̈̈, kişisel isteme ve eylemle açıklama çabasındaki Dövüş Kulübü, son sahnesinde Jack'ın, özgürlüğünü simgeleyen Tyler'ı öldürmesiyle, büyük bir paradoks yaratır. Bu bağlamda çalışma, Dövüş Kulübü filmini Schopenhauer ve Nietzsche'nin nihilizme yükledikleri farkl anlamlandırmalar çerçevesinde analiz etmeyi amaçlamaktadır.

Anahtar Kelimeler: İsteme, Nihilizm, Özgürlük, Dövüş Kulübü

ORCID ID : 0000-0003-2059-5585 \& 0000-0002-0209-4026

E-mail : cenkates83@hotmail.com; mserarslan@selcuk.edu.tr

DOI: $10.31122 /$ sinefilozofi.515297

Geliş Tarihi - Recieved: 20.01.2019

Kabul Tarihi - Accepted: 05.03.2019 


\title{
The Analysis of the Film Fight Club in Schopenhauer and Nietzsche Nihilism
}

\author{
Cenk Ateş* \\ Meral Serarslan**
}

\begin{abstract}
In the history of thought, the problem of human freedom, which is reduced to singular actions without any difference in structure among people, has evolved from human to entirely as a person with Schopenhauer and Nietzsche. The consensus between the two philosophers differs in terms of the way to reach freedom. Schopenhauer's free ideal person, who refuses to will by seizing the reality behind the view, arrives inevitably to nihilism. For Nietzsche, the ideal person, who ignores the dominant values, passes his way by nihilism but can create new values by transcending this point. The disagreement forms in Nietzsche in the axis of passive nihilism, which deprives life of value, and active nihilism, which rejects not life but the interpretation of life with the prevailing moral understanding. This classification in nihilism puts Schopenhuer, who stops the will, and Nietzsche, who destroys the values that stops the will by active nihilism, into two opposing poles. Although it serves different purposes, the word 'no' is affirmed by both philosophers. No is considered the final point in Schopenhauer while it is expressed as a prerequisite for a great 'yes' in Nietzsche.

This divisiveness based on nihilism can be seen in the film Fight Club, directed by David Fincher in 1999. The film, which is open to different readings, focuses on the seeking for meaning by the lead character Jack, who fed up of his life that lead by superego. The film, which presents a sharp critique of capitalism, breaks the illusion of freedom created by dominant values and treats the self-becoming of an individual with the rejection of social values on the actional level. The Fight Club, in an effort to explain freedom with personal will and action, creates a great paradox in the final scene, when Jack kills Tyler, who symbolizes Jack's freedom. The study aims to analyze the film Fight Club in the context of the different meanings that Schopenhauer and Nietzsche have attributed to nihilism.
\end{abstract}

Keywords: Will, Nihilism, Freedom, Fight Club

ORCID ID : 0000-0003-2059-5585 \& 0000-0002-0209-4026

E-mail : cenkates83@hotmail.com; mserarslan@selcuk.edu.tr

DOI: $10.31122 /$ sinefilozofi.515297

Recieved - Geliş Tarihi: 20.01.2019

Accepted - Kabul Tarihi: 05.03.2019 


\section{Giriş}

Yaşamı anlamlandırma bakımından Tanrı ve geleneksel düşünce biçimini reddederek akıl aracılığıyla dünyayı anlama çabası olarak nitelenen düşünce sistemine 'Aydınlanma Felsefesi', bu düşünce sisteminin geliştiği 18. Yüzyıla ise 'Aydınlanma Çağı' adı verilir. Bilimin gelişmesiyle nesneler üzerinde hâkimiyet kuran ve zaferini ilan eden akıl, aynı başarıyı kültür dünyasında kazanmayı amaçlar ve insanı çözümleme gayretine girişir. Böylelikle modern döneme kadar yaşanan süreçte kaderini kendi elinde bulunduramayan insan, Aydınlanma hareketiyle "önyargılara ve cehaletçiliğin karanlığına karşı mücadele ederek" (Folscheid, 2015: 75) özgürleşecek ve mutluluğa ulaşacaktır. Ancak iyimser ve ilerlemeci bu düşünsel sistemin, insanı anlamada hareket noktasını toplum düzeni kaygısıyla kişi değil; sosyal bir varlık, tür olarak insan oluşturur. Bu yönlü bir bakış açısı, eylemi eyleyenden ayırmaya, başka bir ifadeyle bütün olarak insanlar arasındaki yapı başkalığını ıskalamaya neden olur (Kuçuradi, 2013: 3).

Felsefe tarihinde insanı ve insan özgürlügü problemini, tekil eylemlerden kurtararak, kişiyi kendi bütünlüğünde ele alan, sosyal ilişkilerinde eylemlerinin temeli üzerinde duran ve insanı kendisiyle yüz yüze getiren iki önemli isim; Schopenhauer ve düşünsel sistemini Schopenheuer ekseninde inşa eden Nietzsche' dir. İnsanı sosyal bir varlık olarak değil; bağımsız, kişi olarak ele alma noktasında fikir birliğinde olan iki isim, özgürlüğe giden yolu tanımlama bakımından 'evet-hayır' kadar faklı düşüncelere sahiptir. Hareket noktası bilgi problemi olan Schopenhauer, varlığın ne olduğuna yönelir ve insan yaşamı-özgürlüğünü bu temelde tartışır. Filozof, Kant'ın bilinemeyeceğini öngördüğü 'kendinde şey' kavramına açıklık getirerek söz konusu kavram 'İsteme' olarak tanımlar (Schopenhauer, 2014a: 41). İsteme bir anlamda “itki, enerji ya da ilk güçle eşanlamlıdır ve bunun bilinçli hatta üzerine düşünülmüş bir edimle kesinlikle alası yoktur" (Sans, 2006: 33). Dolayısıyla İsteme, dünyanın özüdür ve görünür olan her nesne -beden olarak insan da- onun görünürleşmesi, fenomenidir. Düşünürün başyapitı İsteme ve Tasarım Olarak Dünya (2014a)'da belirttiği şekliyle, kendinde şey olarak isteme, temelde kör, bilinçsiz ve hedefsizdir. Her daim yaşamı isteyen, algıladığımız tüm nesnelerin ya da canlıların varoluş sebebidir ve kendini farklı boyutlarda nesneleştirerek görünürleşir. Dolayısıyla gördüğümüz ve algıladığımız her türlü fenomen, kendinde şey olarak istemenin vücut bulmuş şekline karşılık gelir.

Schopenhauer, nesneleşmenin üst basamaklarında yer alan organik dünyada, ortaya çıkan her türlü ıstırabı ve acıyı, sonsuz- doyumsuz kendinde şey olan istemeyle ilişkilendirerek (Schopenhuer, 2014b: 7), Leibniz' in aksine "dünyayı olası bütün dünyalar arasında en kötüsü" (Aktaran, Salter, 2009: 235) ilân eder. Geleneksel özcü anlayıştan, öze atfedilen kutsallı̆̆ reddetmesi bakımından farklılaşan düşünür, Varlık'1 tanımladıktan sonra, onun insanla olan ilişkisine yönelir.

Schopenhauer felsefesinde, istemenin nesneleşmesinin zirvesinde yer alan insan sayısız ihtiyaca sahiptir. Yokluktan beliren ihtiyaç ya da arzu, bu anlamda hoş olmayan bir duygudur ve kökensel olarak acıya karşılık gelir. Nitekim düşünüre göre, giderilemeyen her istek acıya yol açtığı gibi, tatmin edilen her istek de, kısa bir doygunluğun ardından yerini derhal yeni bir isteğe bırakır (Schopenhauer, 2014a: 145). Kişisel istemeyi, kendinde şey olan istemenin görünürleşmesi olarak ele alan ve her türlü acı ve sefaletin sebebi olarak niteleyen Schopenhauer için yapılması gereken, kişisel istemeden kurtulmaktır. Ancak istemeyi reddetmek, bir anlamda kişinin kendini yadsıması anlamına geldiğinden, söz konusu durumu gerçekleştirmek, bu düşünce sisteminde oldukça zor görülmektedir. Çünkü istencin reddi ancak zihinsel bir 
işlevle mümkün olabilmekteyken, zihin, insana-bedene ait olması sebebiyle ancak temel istemenin uşağı konumundadır. Neredeyse imkânsız olan bu yadsımaya erişebilmenin yolu, Safranski'nin (2015: 357) de belirttiği gibi acı ve istıraplarla yetkinleşmek ve istemenin sebep olduğu yıkımı görebilmekte yatar. Kişi dünyaya içkin acıyı, yaşanan savaşlara, hastanelere ve hapishanelere bakarak görebileceği gibi, kendi bedeniyle de tecrübe edebilir. Nitekim Schopenhauer felsefesinde beden, kişinin bilen özneden önce isteyen özne olduğunu anladığ1 yere işaret eder. Bu bakımdan beden, bir yönüyle Schopenhauer'ın tasarım olarak tanımladığı nesneler arasında bir nesne, diğer yandan istemenin kendini doğrudan duyurduğu bir ikili bir yapıdır. Schopenhauer'ın ifadesiyle "istemenin nesneleşmesi", var olma arzusudur (2014a,: 45). Bu noktadan hareketle kişinin, içsel deneyim aracılığıyla "kendi bedeninde var olan içsel istenç gerçekliğinden yola çıkarak var olan her şeyin doğasına hükmeden kendinde şeyi, yani istemeyi, dolaysız bir şekilde bilmesi olanaklıdır" (Schopenhauer, 2014c: 16). İnsanın öncelikle isteyen özne olduğu düşüncesiyle Schopenhauer, tanrısal ya da düşünsel bir öz yanılsamasını kırarak, her türlü yıkıma sebep olan bencil bir istemeden ibaret olduğunu anlayan insanın, özgürlük adına ne yapması gerektiğine odaklanır. Özgürlüğü varlık boyutunda ele alan Schopenhauerci anlayışın çözüm önerisi, tahmin edileceği üzere istemeyi inkâr etmeye dayanır ki, söz konusu inkâr hiçliğe geçişi, bir anlamda Schopenhauer nihilizmini ifade eder.

Diğer yandan nihilizmden bahsedildiğinde akla gelen isimlerin başında şüphesiz Nietzsche gelir. Gençlik döneminde dünyaya ve insana yönelik düşünceleriyle ateşli bir Schopenhauer savunucusu olan filozof, yaşamının ilerleyen yıllarında normatif olarak değerlendirdiği Schopenhauer'ın karamsar felsefesini şiddetle eleştirerek, yaşamı, dolayısıyla arzuyu ve istemeyi olumlayan fikir arayışına girişir (Magee, 2001: 236). Bu arayış Nietzsche'yi, Schopenhauer' in olgusal dünyaya yönelik isteme kavramını anımsatsa da içerik olarak onu tersine çeviren ve felsefesinin odak noktasına yerleştireceği ' güç istemi'ne götürür. Bir anlamda Varlık' 1 oluş olarak niteleyen Nietzsche, oluşu da güç isteminin toplamı olarak değerlendirir. Filozofa göre "Bu dünya kudrete yönelik iradedir ve bunun dişında bir şey değildir!" (Nietzsche, 2002: 501). Schopenhauercı istemenin tersine çevrilmesi, tam da söz konusu kavramın güce yönelmesi noktasında açığa çıkar ve Nietzsche' nin insan yaşamına yönelik fikirleri bu doğrultuda şekillenir; "Sizin kendiniz de kudrete yönelik bu iradesiniz ve bunun dişında hiç bir şey değilsiniz! " (2002: 501). İnsanın da 'özünde' güç isteminden başka bir şey olmadığına yönelik bu saptama, Schopenhauer' $ı$ istenci yadsıma felsefesinin, yabancılaşmaya yol açtığını öngörür. "Nerde canlı gördüysem, orda güç istemi gördüm; uşağın isteminde dahi, efendi olma istemini gördüm" (Nietzsche, 1964: 132) ifadesiyle bu savı destekleyen Nietzsche, Schopenhauer' in son halkasını oluşturduğu nihilizmden kurtulmayı amaç edinir. Nietzsche, nihilizmi "En yüksek değerlerin değerden düşmesi" (2002:25) olarak ifade eder ve nihilizmin trajik Yunan döneminden bu yana insanlığa musallat olduğuna düşünür. Filozofa göre, değerden düşen en yüksek değer yaşamın kendisidir. Bu bakış açısıyla Nietzsche'nin, Sokrates'le başlayan düalist anlayışın yaşamı değersizleştiren değerlendirme sisteminden Schopenhauer'ın da kurtulamadığını düşündüğ ü söylenebilir. Nitekim filozofun, başyapıtı Güç İstenci'nde (2002) yer verdiği nihilizm sinıflamasında ${ }^{1}$, Schopenhauer'ın temsil ettiği istemeyi reddetme felsefesi, zayıf karamsarlık olarak nitelenen edilgen nihilizme denk düşer.

1 Nietzsche, Güç İstenci (2002)'nde nihilizmi tarihsel olarak Orijinal nihilizm ve Avrupa (gerçek) nihilizm olarak ikiye ayırır. Orijinal nihilizm, Tanrı inancıyla yaratılan üstün değerlerle yaşamı hiçleştirmek anlamına gelir ve Schopenhauer'den ödünç aldığı maya perdesi kavramıyla, nihilizmin kendini gizlediğini ifade eder. Tanrının ölümüyle simgelenen modern dönemle birlikte, gerçekliğin üzerindeki maya perdesi kalkar ve yanılsama açığa çıkar. Nietzsche, yaşama verilen değerlerin değersizliğinin fark edilmesini Avrupa ya da Gerçek nihilizm olarak tanimlar. 
Nietzsche' de etken-edilgen nihilizm ayrımı, kendisinden yaklaşık yarım asır önce Schopenhauer tarafından sessizce kaldırılan Tanrının cenazesini, "borazan öttürerek" duyurmasıyla (Safranski,2015), açığa çıkar. Geleneksel değerlerin çöküşünü simgeleyen Tanrının ölümü, Nietzsche için insanın verdiği en büyük sınavdır, çünkü kendi değerlerini yaratma şansını elde etmiştir. Ancak modern dönemle birlikte 'ortak akıl', insanın yeni değer yaratma şansını elinden almış, başka bir ifadeyle insan, yeni değerler yaratmak için kazandığı en büyük şansı kaçırmıştır. Yaşamı değerlendirme sisteminin tekelde toplanmasını, yeni değerler yaratma girişiminde en büyük engel olarak gören Nietzsche, bahsi geçen tutumun insanlığı pasif bir pozisyona düşürdüğünü iddia eder. Önce Tanrı inancı ve sonrasında modern dönemle birlikte insanın isteklerinin köreldiği, insanlığın istemelerine gem vurulduğu fikri Nietzsche felsefesinde insanı, üstün değerlerin yokluğuyla karamsarlığa iter ve kişi “Tanrı' yı, iyiyi ve doğruyu, üst duyarlılığın tüm formlarını inkâr eder. Hiçbir şey doğru değildir, hiçbir şey iyi değildir, Tanrı ölmüştür. İstenç hiçliği, bir hiçlik istenci için artık yalnızca bir araz değil, ama en uç noktada, tüm istencin inkârıdır" (Deleuze: 2001:113). Yaşamdan tiksinti olarak da değerlendirilebilen yaşamdan vazgeçiş karamsarlığını Nietzsche, edilgen nihilizm olarak tanimlar.

Hiçlik isteminden, istenç hiçliğine evrilen bu süreçte edilgen nihilizm "değerlerin bulunmadığ1 bir dünya"yı işaret eder (Diken, 2011: 59). Metinlerinde 1srarla etken-edilgen nihilizm arasındaki ayrıma vurgu yapan Nietzsche için mesele, modern öncesi dönemi ifade eden orijinal nihilizmin, yaşamın değerini değersizleştirmesine rağmen, insanın içindeki istenci yaşatması, yani hiçliği istemesi ancak modern dönem sonrasında yaşama dair değerlendirilecek bir değerin olmadığına yönelik inancıdır (Deleuze, 2001: 112). Nihilizme yönelik bu yönlü bir sınıflandırma, güç istemini daha anlamlı kılar çünkü tam da burada "zayıflık ve güçlülük ortaya çıkar: Zayıflar kırılıp dökülürler, daha güçlüler kırılmayan her şeyi yıkarlar, en güçlü kişilerse yargılayan değerleri arkada bırakırlar" (Kuçuradi, 1967: 82). Bu bakış açısına göre zayıflar, karamsarlığı ve yaşamdan vazgeçenleri temsil eden edilgen nihilizme; güçlüler, modern dönem pratiklerine karşı koyan ve geleneksel değerleri yıkmak isteyen, etken nihilizme karşllık gelir. Her iki nihilizm türünde de dikkat çeken temel unsur 'hayır'dır ancak edilgen nihilizm hayata; etken nihilizm modern dönemin değerlendirme sistemine hayır anlamı taşır. Meseleye nihilizm ve güç istenci denkleminde bakmak Nietzsche' nin, Schopenhuer felsefesine karşı eleştirel tavrını anlamayı kolaylaştırır. Nitekim filozofa göre, Schopenhauer'ın ulaştığı son nokta, en yüksek değerin, yaşamın değerini küçülterek ulaşılan ve kişinin kendini inkâr noktasıyla sonlanan karamsar -edilgennihilist bir felsefedir. Bu düşünceyi, Avrupa nihilizminin henüz emekleme aşaması olarak değerlendiren Nietzsche'ye göre (2002: 24) çözüm trajik bir güç kötümserliğidir. Tanrısal ya da modern dönemim yanılsamalı değerlerini kavrayarak, oluşu, yani realiteyi kavramış gücün karamsarlığı, "şimdiye kadar olanı tümüyle hiçlemek, anlamsızlığı idrak etmek ve yabancı bir dünyaya düşme tehlikesine rağmen ısrarla yürümektir (Heidegger, 2008: 72-73). Dolayısıyla Nietzsche felsefesi anlamayı, eylemekle; duyular üstü dünya adına düşman ilan edilen bedeni ve onun arzu-isteklerini fark etmeyi, sözü geçen isteklerin peşinden gitmekle özdeşleştirir. Elbette bunu yapabilmenin yolu, Tanrı inancının getirisi köle ahlakını ve modern dönemin uyum illüzyonunu yıkıma uğratarak, istemeyi - güç istemini istemektir (Nietzsche, 1964: 44-51). Bu bakımdan Nietzsche felsefesinde yabancılaşmanın sona ermesi anlamına da gelen bedenin keşfi aracılığıyla kişinin kendini tanıması, insanın kendi üzerine düşünmesiyle değil; tersine gücünü tecrübe etmesiyle olanaklı hale gelebilmektedir. Kişi, dışardan gelen 
yönlendirmeleri reddederek, kendi yaşamını özgürce yapılandırmalı (Akarsu, 1979: 125), pasif konumunu terk ederek aktif nihilizm sürecine girmelidir.

Görüldüğü gibi dünyanın 'ne'liğine dair, varlık ve oluş fikirleriyle farklılaşan Schopenhauer ve Nietzsche, bu öngörü üzerine inşa edilen insan yaşamına yönelik fikirleriyle iki zit kutba yönelirler. Başka bir ifadeyle Schopenhauer için, özünde tek olan ancak zaman ve mekân aracılığıyla nesneleşerek görünüş formuna giren temel isteme, acının kaynağı olduğundan, insan da söz konusu kendinde şey olan istemenin nesneleşmesi anlamına geldiğinden, yapılması gereken insanın istemesiyle arasına mesafe koymasıdır. Yalnızca kendine yönelik bu bencil itkiden kurtulmak, ancak merhamet duygusuyla mümkün olabilir. Diğer yandan Nietzsche için dünya güç istemlerinin toplamı anlamına gelen oluştur ve insan da temelde güç isteminden başka değildir. Bu bakımdan Nietzsche' ye göre yapılması gereken, kişinin kendi olmasının önündeki engellerin tümünü yok etmesidir. Soruna getirilen çözüm, istemeyi yadsımakla değil, istemeyi istemekle mümkün olabilir.

Bu bağlamda çalışma, yukarıda değinilen kavramsal çerçeveden hareketle 1999 yapımı Dövüş Kulübü'nü Schopenhauer ve Nietzsche'nin nihilizme yükledikleri farklı anlamlandırmalar ekseninde felsefi açıdan irdelemekle birlikte, iki düşünürün nihilizm temelinde sinıflandırdığı insan tiplerini, filmin başkarakteri Jack'ı mercek altına alarak açıklama amacındadır. Adı geçen düşünürlerin özgürlüğe ulaşma yolunda betimledikleri insan sınıflamasında anahtar kelime ise istemedir. Dolayısıyla çalışmada, yaşadığı özgürlük yanılsamasından kurtulmayı hedefleyen Jack karakteri, isteme kavramı temelinde analiz edilmiştir. Dikkat çekilmek istenen husus, özgür olma çabasındaki bireyin istemeyi olumlaması ya da susturmasının kendisi ve toplum üzerinde yarattığı etkidir. Söz konusu düşünceden hareketle, kişinin kendi olma serüvenini ele alan filmin, isteme noktasında hangi filozofun felsefesini takip ettiği çalışmanın problemini oluşturmaktadır.

Belirlenen amaç doğrultusunda çalışma, filmi betimsel analiz yöntemiyle incelemeye tabi tutmaktadır. Bu yönteme uygun olacak şekilde, filme ait sahneler, diyaloglar ya da bazı görsel unsurlar metonimik olarak yorumlanmış; parça-bütün ilişkisi bağlamında ve çizilen kuramsal çerçeve özelinde tahlil edilmiştir.

\section{Dövüş Kulübü ve İste(me)me}

Feminist çözümlemeden ideolojik çözümlemeye kadar farklı okumalara açı olan Fight Club (Dövüş Kulübü, David Fincher, 1999), temelde kişinin kendi olma serüvenini ele alır. Filmin ilk sahnelerinde Amerika'da bir sigorta şirketinde risk uzmanı olarak çalışan, tüketim toplumuna adapte olmuş ve çevresine karşı bezgin tavırlarılyla tipik modern insan davranışları sergileyen Jack karakterinin yaşamına tanıklık ederiz. Jack'in düşlediği hayat, kişiliğini yansıtacak mobilyalara sahip olabilmek, el yapımı ürünlerle kendi farklılığını ortaya koyabilmek ve yaşadığı uykusuzluk problemine çözüm bulabilmektir. Doktorunun tavsiyesiyle kanser hastalarının terapi gruplarına katılan Jack, ölüm gerçeğiyle yüzleşmiş olan bu insanlar arasında, sağlıklı olmanın verdiği arınmayla uykusuzluk probleminin üstesinden gelir. Filmde anlatıcı olarak da yer alan Jack karakteri, birçok sahnede olduğu gibi bu sahnede de kendisine dair ipuçları verir. Yaşadığı tecrübeyle umudun yok olmasının insanı özgürleştirdiğinden söz eder. Ancak umutsuzluğu yaşayan kendisi değil; hastalardır. Daha sonra adının Marla Singer olduğunu öğrendiğimiz bir kadın terapi gruplarına katılır. Jack, Marla'nın hasta olmadığını, terapi gruplarına bedava eğlence olarak baktığını fark eder ve Marla'ya düşmanlık besler. Söz konusu duygu aslında Jack'in kendiyle yüzleşmedir çünkü 
her ikisi de rahatlama ihtiyacıyla bu topluluğa katılmıştır. Yani ikisi de yalan söylemektedir. Jack bu yüzleşmeyle tekrar uykusuzluk çekmeye başlar. Diğer yandan Marla'nın geleceğe dair bir kaygı taşımadan, "her an ölebileceği, asıl trajedinin yaşamak" olduğuna yönelik hayat felsefesi Jack'1 etkiler ve kendi sıradan yaşamını gözden geçirmesine neden olur. Bahsi geçen sorgulama, Jack'1 şimdiye kadarki isteklerinden (mobilya, duvar saati, yin-yang şeklinde kahve sehpası) vazgeçme ya da Marla'nın da etkisiyle her an ölebileceği fikriyle dolu dolu yaşayarak, yaşamdan çok daha fazla şey isteme ikileminde bırakır. Böylelikle filmin temel meselesiyle de karşılaşmış oluruz: İstemeyi olumlama ya da reddetme.

Marla karakteri Jack'ın yaşayacağı serüvende önemli bir yer tutar. Terapi gruplarında hastaları yaşama bağlamak adına yapılan meditasyon seanslarının birinde rehber, hastalardan mağaralarına girmelerini ve iyileştirici enerji, güç aldıkları hayvanı bulmalarını ister. Jack'in düşünde, güç aldığı 'hayvan'ın Marla olduğunu görürüz. Bu sahne Schopenhauer'ın, insanın doğuştan isteyen bir canlı olduğu ve kişisel istemenin güdüler aracılığıyla istemeyi harekete geçireceği yönündeki savını akla getirir. Nitekim filozofa göre isteme, kendini en fazla cinsel yaşamda hissettirir (Safranski, 2015 394). Jack'ın izleyiciye söyledikleri bu anlamda dikkat çekicidir; "Eğer bir tümörüm olsaydı adını Marla koyardım. Damağındaki o küçük çizik, dilinle oynamasan hemen geçer ama duramiyorsun, oynuyorsun". Bu replikle karakterin başına geleceklerin Marla'yla ilgili olduğunu anlarız. Schopenhauer'ın her tatmin yerini derhal başka bir istemeye bırakır savını doğrularcasına, uykusuzluk problemini, meditasyon gruplarıyla çözüme kavuşturan Jack, yeni istencine yani Marla'ya ilgi duymaya başlar. Yaşadığı duygulanım neticesinde Jack, tekrar uykusuzluk çekmeye başlar. Başka bir ifadeyle Marla, Jack'in arzusunu canlı tutma mekanizmasıdır ve film boyunca onun hayatında farklı amaçlarla da olsa yer almaya devam edecektir. Ancak Jack karakterinin, Marla aracılığıyla yaşayacağı değişime geçmeden önce, karakterin Schopenhauer ve Nietzsche felsefesinde, isteme merkezli insan kategorilerinin hangisinde yer aldığına değinmek gerekir.

\section{Sürü İnsan1- Fabrikasyon İnsan}

Temelde nihilizm ekseninde şekillenen ancak benzerlikten çok farklılık içeren Schopenhauer ve Nietzsche felsefesinin nadiren birleştikleri noktalardan biri, hayatın ıstırap ve kederle dolu olduğu, insanın anlamsız bir dünyada yer aldığı fikridir. Nietzsche, Schopenhauer'a özgü bu kötümser öncüllere katılır ancak, umutsuzluğun doğurduğu eylemsizliği, istencin reddini kabul etmez. Bu bağlamda, her iki düşünürün yaşama karş1 takınılan tavırda, eleştirdikleri ve ideal insan tipleri de farklılık arz eder (Dolson, 2009: 402-403). Schopenhauer için sıradan ya da fabrikasyon ${ }^{2}$ olarak ifade edilen insan tipi, belirli bir zaman diliminden bağımsız olarak şimdinin eline geçmiş, neden istediğini bilmeyen ama tabiatı gereği isteyen, rastgele yaşayan kişi anlamına gelir (Schopenhauer, 2014a: 133, Kuçuradi, 2013: 70). Nedensellik bağından kopmayan fabrikasyon insan, gündelik işlerde boğulan ve yaşamını sürdürme gayretinde, kendisine sunulanı isteyen ama yine de isteyen insandır. Schopenhauer'ın insanın zihin süreciyle ilişkilendirdiği ve kendinde şey olan istemenin zaman-mekân-nedensellik formuyla nesneleştiği tasarım dünyasına gerçeklik atfeden fabrikasyon insanı, acı ve mutluluğu temelden farklı duygulanımlar olarak nitelendirir. Başka bir ifadeyle fabrikasyon insan, gözündeki maya perdesi ${ }^{3}$ ile, olduğu gibi

2 Kuçuradi (2013:53-55), Schopenhauer felsefesinde, gerçeğin farkına varamayan özü gereği isteyen insanı fabrikasyon insan olarak niteler.

3 Temeli Hindu felsefesine dayanan, gerçeğin çıplak olarak idrak edilemediği durumda, farklı şekillerde algılanmasını ifade eden kavramdır. Schopenhauer felsefesinde bireysellik ilkesi olarak tanımlanan zaman-mekan- 
olan, yani istemenin nesneleşmesi olarak tıpkı temel isteme gibi bilinçsiz isteyen kişi anlamına gelir. Nitekim filozofa göre insan da, nesneler arasında bir nesne olarak, doğumuyla temel istemeyi olumlamış ve ona göre programlanmıştır. Bu insanlarda bilginin, her daim istemenin emrinde olduğunu düşünen Schopenhauer, karamsar felsefesinde ilk kez toplumsal- siyasal koşullara yer vererek fabrikasyon insanın maya perdesinden kurtulamamasına açıklık getirir. Filozofa göre kişinin temel istemeden ibaret olduğunu anlamasının önündeki zayıf engellerden biri, modern dönemin boş zaman bırakmayan çalışma temposudur. Söz konusu yoğunluk içinde, gerçekliği algılayacak zaman bulamayan insan, ister istemez hazcılığa yönelir ve ilgileri kendi istemeleriyle sınırlı kalır. Fabrikasyon insan bu bağlamda, temel istemenin kendi amaçları için talep ettiği kadar akla sahip, mesleği dışında düşünsel aktiviteye sahip olmayan, hayatın doğuştan kölesidir (Schopenhauer, 2018: 124). İstemeyi mekanikleşmeyle eşleştiren Schopenhauer' in siradan-fabrikasyon insanı, insan kategorisinde en alt basamakta yer almakla birlikte, Nietzsche' deki insan sınıflamasını anlayabilmek için de önem taşır. Nitekim istemenin susturulması oranında yükselen Schopenhauer insanı, Nietzsche' de aksi yöne, zemine düşer.

Schopenhauer' da istemenin tutsağı olmuş, özgür olamayan fabrikasyon insanın aksine Nietzsche'nin en alt basamakta yer alan insan sınıfında, öte dünya inanışının sebep olduğu yaşamı değersizleştirme pratikleriyle hiçlik istemindeki 'sürü insanı' ve tanrının ölümü modernizmle birlikte, bu dünyayı hiçleştirme isteğini de yitiren ve eylemsizlik bataklığında sürüklenen 'son insan', istemeyen insan yer alır (Nietzsche, 1964: 53). Temelini Nietzsche'nin Ahlakın Soykütü̈̆̈̈̈ Üstüne (2013) adlı eserinde derinlemesine ele aldığı efendi-köle ilişkisinden alan sürü ahlakı, gücünü kullanamayan ve bu eksikliği Hıristiyanlıkla evrenselleştiren bir yapıyı ifade eder. Reaktif bir karaktere sahip olan köle ahlakı, yeni değerler yaratamayan ve ancak efendinin değişime öncülük eden iyi anlayışını, kötü olarak değerlendirebilen bir ahlak anlayışıdır. Copleston'un da belirttiği gibi, Nietzsche felsefesinde aşkın varlığa olan inanç, insanın duygularına ve kendini özgürce geliştirme yeteneğine ket vurmasına yol açar (1998:164). Dolayısıyla Nietzscheci literatürde alt kategoriyi temsil eden sürü insanı, realiteyi kendi gözleriyle değil; bağlı bulunduğu moralin değerleri üzerinden değerlendiren, kendisinden önce belirlenen değerlere itaat eden insana karşılık gelir. Doğru ve yanlış algısı, mutlak buyruklara göre şekillenen bu insan türü, üstün değerler adına yaşamı yadsıyan, ezginliğini barışseverlik, toplumdaşlık, saygı, yardımseverlik ve eşitlik kavramları ardında gizleyen insan profilidir. Daha net bir ifadeyle, güçsüzlüğünü gizleme çabasında, ahlaki kurallara boyun eğen insandır (Kuçuradi, 1967:50-55). Varlığını her daim devam ettirmekle birlikte, daha çok modern dönem öncesi insanla ilişkilendirilen bu insan tipi, içinde bulunduğu dönemin değerlerine aşkın bir anlam yükleyerek, hiçlik duygusuyla karşılaşmamış ve yanılsama dünyasında yaşamıştır. Ancak inandığı değerler uğruna, içinde yaşamı değersizleştirme isteği duyan sürü insanı, görece modern dönemin her şeye karşı kayıtsız ve istencini öldürmüş insanından daha üstündür. İki insan tipini ayıran temel nitelik, son insanın tanrı inancını, dolayısıyla ahlak değerini yitirmesidir. Ancak duyular üstü mutlak'a olan inancın yıkılması, yaşadığı boşluk duygusundan kurtulmak isteyen insanı, başka bir mutlak'a boyun eğmeye zorlamıştır. Bu anlamda yeni otoritenin adı modernizm; yaşadığı anlamsızlık ve değersizlik duygusunu

nedensellik aracılığıyla kişinin temel İstemeyi ve kendini onun bir parçası olarak görmesinin önündeki engel anlamında kullanılır (Safranski, 2015:364). Nietzsche, söz konusu kavramı Schopenhauer'a benzer şekilde gerçeğin zihin tarafından farklı şekillerde algılandığını ifade etmek için kullanır ve Sokratik dönemden başlayarak yaşamı değersizleştiren bakış açısına, başka bir ifadeyle insanın içindeki gücün farkındalığını engelleyen nihilistik kültüre gönderme yapar. 
modernitenin pratikleriyle aşmak isteyen yeni insan tipi de, söz konusu otoriteyi keşfetmiş olan son insandır (Pearson, 1998:138). Bir yandan en yüksek değer olarak görülen tanrıyı öldürerek sürü insanından ayrılan son insan, diğer yandan anlamı, dış yapılarla inşa ederek tekrar sürü insanına yaklaşmaktadır. Nietzscheci perspektifte kırılan yanılsamanın yerine, yeni bir yanılsamaya bağlanan son insan, bu tutumuyla tanrının ölümünü anlamsızlaştırarak, realiteyi kendi gözleriyle görme şansını değerlendiremeyen insan anlamına gelir. Bahsi geçen durum nedeniyle Nietzsche, son insanı en tehlikeli insan tipi olarak nitelendirir (1964: 233). Onun tehlikesi, kaybettiği değerlerin sebep olduğu manevi boşluğu haz ve mutluluk arayışla doldurma çabası ve öznelliğini reddederek, itaati meşrulaştırmasıdır. Böylelikle birey olabilme yolunda mücadele verebileceği bir değeri bulunmayan bu insan tipi, yaşamı üstün değerler adına değersizleştiren sürü insanının yerine, değerin kendisini değersizleştirmesi, bir anlamda yaşamı değersizleştirmesi bakımından en tehlikeli insan kategorisini sembolize eder (Kaufmann,2009: 61-63). Nietzscheci bakış açısıyla gerçeğin anlamsızlığına, en az kendinden önceki dönem kadar uzak olan modernizm, insanı öznelliğinden bir kez daha kopararak, sürü insanından daha tehlikeli son insanı ortaya çıkarmış ve nihilizmi beslemiştir denebilir.

Son insanı çobansız bir sürüye benzeten Nietzsche için, "Bu insan tipinde herkes aynı şeyleri ister ve birinin diğerinden farkı yoktur" (1964:35). Hayatın 'ne'liği üzerine düşünmeyen, yaşamın anlamından kuşku duymayan ve hazzı, yaşamın tek gayesi olarak gören son insanla, kendini aşma girişiminden uzak ve yaşama yeni bir değer yorumu getirmeyen uyuşturulmuş insan kastedilir. Hedonist bir yaşam içinde sürüklenen son insan, nihilizm çıkmazında maddi tatminlerle teselli bulur ve içinde yaşadığı morali farklı görenleri yadsır. "Tanrı'ya ya da onun yerini alan herhangi bir puta: bilim'e, vatan'a, soy'a ve buna benzeyen şeylere" (Kuçuradi, 1967: 72) inanması, onu robotlaşmış bir hayat içerisinde eylemsiz bir boşunalıkla savrulmaya götürür. Bu tutum aynı zamanda, tanrıyı öldüren tepkin kuvvetin erimesi manasına da gelir. Konuyla ilgili Deleuze, “Tanrı'dan Tanrı'nın katiline, Tanrı'nın katilinden son insana” (2010: 127) ifadesiyle, nihilizm silsilesinin son insanla devam ettiğini düşünür.

Bu bakımdan insanlığı, nihilizm bataklığında eylemsizliğe gömülmüş sürü olarak değerlendiren Nietzsche'ye göre, yapılması gereken, insanı tektipleştiren anlayışın dışına çıkılarak, yeni değerler yaratılmasıdır. Diğer yandan herhangi bir dönemsel ayrım yapmadan, insanın her daim istediğini ve bunun sonucu olarak dünyanın işkence merkezini andırdığını iddia eden Schopenhauer için de, yapılması gereken, neden istediğini bilmeyen, yapısı gereği isteyen sürüden ayrılmaktır. Toplumdan farklı gerekçelerle de olsa uzaklaşmak gerektiği noktasında birleşen iki düşünürü ayrıştıran temel öge, Schopenhauer'ın istemeyi reddetmesi; Nietzsche'nin ise insan istemesine farklı gerekçelerle gem vurulduğu ve bunun aşılması gerektiği yani insanın istemesi gerektiği fikridir.

Bu bağlamda Jack karakteri, Schopnhauer felsefesinde mobilya, sehpa gibi sıradan da olsa isteklere sahip biri olarak, Nietzsche felsefesindeyse modern dönemin tutsağı, istemesi gerekenleri isteyen, yani istemeyen, dönemin moral anlayışına itaat eden, birey olamayan biri olarak düşünülebilir. Ancak Jack, insanın yaşama yönelik takınması gereken tavırda 'evet' 'hayır' kadar farklılaşan iki düşünürün, ulaşmak istedikleri nihai noktayı saptamak adına tasarladıkları insan sinıflamasında aynı kategoride, el alt basamakta yer alır: Schopenhauer' da bilinçli olarak değil; özü gereği isteyen fabrikasyon insan, Nietzsche' de morala göre yaşayan ve yeni değer üretemeyen, acıdan kaçarak hedonizm bataklığındaki sürü-son insan.

Filmdeki ilk kırılma noktası, karakterimizin içinde bulunduğu durumdan çıkmak 
için seçeceği yöne ilişkindir. Schopenhauer'de, kişisel istemeyi harekete geçiren dişsal neden olarak tanımlanan 'güdü' ye (2014a: 49) örnek teşkil edercesine Jack'ın mağarasındaki güç aldığı 'hayvan', Marla, Jack'1 kişisel isteme yönünde harekete geçirir. Bu duygulanım sonucu Jack, kendi olamadığı, isteklerinin yönlendirildiği fikrinden hareketle, kendisine dayatılanları değil; kendi olmaya, içindeki gücü keşfetmeye karar verir. Dolayısıyla yüzünü Nietzsche felsefesine çevirir. Ancak Jack, kendi istemelerine o kadar uzaktır ki, film boyunca gerçekleştirdiği istemelerini bir yabancı gibi dışarıdan izler ve Tyler adındaki bu yabancıyla tanışır. Tyler, Jack'ın içindeki istemedir, güç istencidir. Susturulmuş ve unutulmuş benliğidir.

Hakim moral anlayışın dışında yaşayan, yaşamı kendi kararlarıyla sürdüren ve içgüdüleriyle hareket eden Tyler, tüm insanlığın bir yanılsama içinde olduğunu, kendilerine vaad edilen hiçbirşeyin olmayacağını, dostluk, ahlak, vicdan gibi kavramların uydurma olduğunu düşünür. Herkes için değerli olan onun için değerli değildir. Bahsedilen özellikleriyle Tyler, kendi olmaya çalışan, kendi isteklerinin peşinde koşan, sahip olmaktan nefret eden biridir. Herkesten farklı olan bu 'yabancının' hakim moral anlayışının dışında oluşu, tıpkı Nietzsche felsefesinde olduğu gibi, yaşama karşı 'hayır' değil; yaşamı yorumlama şekline, tüketim kültürüne, meta fetişizmine, kişiliği silen dayatmalara, oluşturulan sözde değerlere karşı bir 'hayır' dır. Tyler, Jack' ın evini imha ederek (filmin ilerleyen bölümlerinde bunu Jack' in kendisinin yaptığını öğreniriz), kişinin özgür olması için önce herşeyini kaybetmesi, tüm alışıla gelmiş düşünce kalıpları ve alışkanlıklarını yitirmesi gerektiğini düşünür. Tyler'ın bakış açısı, nihilizminden kurtulmak için nihilizmin yaşanması gerektiğini düşünen Nietzsche'yle aynı yöndedir. Bu bakımdan Tyler'ın Jack'a söylediği cümle önemlidir “sahip oldukların, sonunda sana sahip oluyor".

Kalacak bir yeri olmayan Jack, Tyler'la birlikte kalmak istediğini söyler ancak bu isteğin kabul edilmesi için Tyler'ın suratına yumruk atması gerekir, üstelik bunu isteyen Tyler'ın kendisidir. Jack, zor da olsa bu isteği kabul eder ve dövüşmeye başlarlar. Bedensel acı özelinde, acıdan kaçma gayretindeki Jack, bu dövüşten kendisini de şaşırtan bir zevk alır ve Tyler'ın evinde yaşamaya başlar. Acıdan aldıkları haz Jack ve Tyler'ın, yalnızca erkeklerin katılabildiği bir dövüş kulübü kurmasına yol açar. Bu yolla Jack, Marla'yla tanıştıktan sonra nükseden uykusuzluk problemine yeni bir çözüm bulmuş olur. Haftanın belirli günleri, gittikçe genişleyen bir kalabalık, birbirlerini kıyasıya dövmeye başlar. Bedensel ve duygusal değişimine aldırış etmeyen Jack için dövüş, yaşadığının farkına varması anlamını taşır. Tyler'la tanışmadan önce değerli olan herşey, Jack için önemsizleşir ve eski yaşamından çok farklı bir hayat tarzını benimsemeye başlar. Yaşadığı değişimle ilgili hislerini "Dövüşten sonra, hayatımdaki her şeyin önemi azaldı... Bu hayat tarzı herkesin dilinin ucundaydı, biz adını koymuştuk, biz sadece okumayı çözmüştük" ifadesiyle izleyiciye aktarır. Bahsi geçen durum, Nietzsche'nin sürü-son insanından kurtulma çabasını işaret eder. Herkesin dilinin ucunda olan ama söyleyemediği şey, insanın alışılagelmiş değer yargılarıyla unutulan ve herkesin içinde bulundurduğu güç istenci olarak yorumlanabilir. Bu bakış açısıyla Tyler'ın, Jack'in içindeki gücü temsil ettiği fikri ağırlık kazanır.

Tyler, Nietzsche felsefesinde, son insanlar ve onların değerlerinden uzaklaşarak yeni bir kategori oluşturan, dönemin değerlerine başkaldırmış ve yaşamı olumlayan 'özgür insan'a karşılık gelir. Edilgen nihilizmden kurtulmuş, egemen moral anlayışını, putları yıkma gayretindeki özgür insan, Nietzsche için kişinin kendi olabilmesi serüveninde mutlaka uğranması gereken bir duraktır (1997: 16-17). Eyleme geçmiş ve aktif nihilist özelliği gösteren 
bu insan tipi, Schopenhauer felsefesinde fabrikasyon insandan styrılarak, bilinçli bir şekilde isteyen, akıllı insan kategorisini oluşturur. İstemesini gerçekleştirmeye engel olan herşeyi diğer kişilerde dahil- yok etme pahasına istemesini olumlayan akıllı insanın duyumsadığ1 tek şey, kendi istemesidir (Kuçuradi, 2013: 73, Schopenhuer, 2014a: 251-254). Diğger insanlar bu insan için birer nesne, görüntüden ibarettir ve isteklerinin gerçekleştirilmesi için yalnızca birer araçtır (Schopenhauer 2014a: 136). Temel istemenin varlığını sürdürmek ve çoğalmak amacıyla, insanı yalnızca hizmetkarı olarak kullandığını düşünen Schopenhauer için akıllı insan, kendini dünyanın merkezinde konumlandıran ve kendi tatmini için herşeyi hiçleyen insan anlamına gelir. Bu noktada Jack'in “Ben, bu dünyanın etrafında kalabalık oluşturduğu küçük merkeziyim" ifadesi dikkat çekicidir. Schopenhauera göre dünyanın ve istemenin bir parçası olan, kendisinin anlamsızlığına bir anlam yüklemek amacıyla, boşluktan kurtulma çabasındaki akıllı insan, istencini susturma güçsüzlüğünü, kendine verdiği değerle gizleme çabasındadır ve bu anlamda, sıradan-fabrikasyon insandan farklı olarak yaşama bilerek evet der. İstemeyi bilinçli olumlayış, Schopenhauer'da yaşanan ıstırap ve sefaletin sürmesine gönüllü olarak katılmak anlamına gelir. Geçmişe ait her türlü değerin yıkımını gerçekleştiren Jack, kurmuş olduğu dövüş kulübüyle, Schopenhauercı bakışla her tatminin yeni bir isteme doğurduğu gerçeğinden habersiz olarak, şimdilik acı çekmeye gönüllü insanlarla sınırlı bir alanda tatmin yaşar. Sıradan insandan akıllı insana, son insandan özgür insana dönüştüğünü "herşeyi farklı görmeye başladım", " aydınlandım" gibi cümlelerle ifadeeden Jack, bu bakımdan Schopenhauerci bakış açısıyla suç işleyen bir mahkûmdur. Çünkü Felsefenin Yaban Yılları adlı eserinde, Schopenhauer felsefesinin derin bir analizini yapan Safranski'nin de belirttiği gibi "suç istemede değil, bilgiyle istemededir" (2015: 385). Diğer yandan Schopenhauerci anlayışın mahkûm sandalyesine oturttuğu Jack'i, içindeki gücü keşfetmesi bakımından Nietzsche felsefesinde özgürlüğge giden yolda önemli bir adım atmış, iyileşme sürecine girmiş bir hasta olarak değerlendirmek mümkündür. Nietzsche'nin, yeni bir değer yaratmadan yalnızca yıkıma odaklanan kusursuz-etkin nihilist olarak tanımladığı özgür insan tipi, bedenin farkına olan ve dolayısıyla eyleme - tutkulara öncelik veren insan anlamına da gelir (Pearson, 1998: 252-253). Bu tanımından hareketle, kurduğu dövüş kulübüyle tek gerçekliği olan bedenin üzerindeki acıyla varlığını duyumsayan Tyler’ın, özgür insana karşılık geldiğini söylemek mümkündür.

Nietzche'nin özgür insan tanımında önemle üzerinde durduğu bedenin farkındalığı, dolayısıyla tutku ve arzuların farkedilişi, Tyler karakterinin Marla'yla sevişme sahnelerinde belirginleşir. İçindeki isteme dürtüsünü tetikleyen Marla'ya ilgi duyan Jack, kendisinin yaşadığından habersiz, yani Tyler'ın yaşadığını düşünerek, Marla'yla birlikte olur. Ancak Tyler, Marla'yı, yalnızca bir et parçası olarak görür ve Jack'ın en kısa sürede ondan kurtulması gerektiğini söyler. Diğger yandan dövüş kulübü yayılmakta, her akşam dövüşler düzenlenmekte ve bedenler büyük acılar yaşamaktadır. Yaşamından memnun olan Jack giderek Tyler'a, içindeki özgür insana benzemeye başlar.

Filmde, Nietzsche' nin oluşu kucaklayan Dionysoscu yıkıcılığına ve acıyı olumlamasına ilişkin en dikkat çekici gönderme, Tyler'ın Jack'ın eline kimyasal madde dökerek yaktığ sahnede açığa çıkar. Acılar içinde kıvranan Jack kurtulmaya çabalar ancak Tyler, “yaşadığın en büyük an, kaçma" diyerek Jack'ı acıya dayanaklı kılmak ister. Bu sahnede Tyler'ın söyledikleri doğrudan Nietzsche felsefesine hizmet eder: “Acıyı hisset, acı ve kurban olmadan hiç birşey yapamazsın. Tanrı senden nefret ediyor, bu başına gelecek en kötü şey değil, ona ihtiyacımız yok. Önce teslim ol, korkmayı bırakıp bir gün öleceğini kabullenmelisin. Sadece her şeyi 
kaybettikten sonra özgür kalabilirsin. Aferin dibe biraz daha yaklaştın". Bu cümleleri sanki Tyler değil, tüm moral ahlakı geride bırakan Nietzche' nin aktif nihilist kişisi, özgür insan söylüyor gibidir. Jack her kurtulma girişiminde Tyler tarafından tokatlanır ve yaşamanın en önemli anı olduğu, bundan kaçmaması gerektiği konusunda uyarılır. Sahnenin sonunda acıya dayanaklı hale geldiği düşünülen Jack, Tyler tarafından serbest bırakılır ve dibe biraz daha yaklaştığı için kutlanır.

Tümüyle Nietzsche felsefesine yönelen filmde dikkat çeken temel öğe, Jack'ın aslında Tyler olduğunu henüz fark etmemiş olmasıdır. Jack'a göre tüm bu yaşananları Tyler istemektedir. Schopenhauer'ın istemelerin sonsuzluğu ve her tatmin yeni bir isteğin doğuşuna yönelik görüşüne benzer şekilde, Tylar ve Jack, kendilerine yaşattıkları, Nietzsche tarafından kendi olabilmenin eşik noktasını betimlenen acıyı, dışa yöneltirler. Tyler'ın talimatları doğrultusunda her dövüş kulübü üyesi tanımadığı bir kişiyle kavga çıkarmaya, arabaları yağmalamaya, reklam panolarını sökmeye başlar. Tyler dövüş kulübündekilere ithafen, en güçlü ve en zeki erkekleri gördüğünü ve hepsinin rock yıldızı olacağına yönelik umutla yetiştirildiklerini ancak bunun hiçbir zaman olmayacă̆ını, tam da bu nedenle çok kızgın olduklarını sıklıkla vurgular. Nihilizme yönelik derin bir eleştiri içeren bu ifadeler, Tyler karakterinin kameraya bakarak konuşması bakımından oldukça önemlidir. "Sizler, işleriniz, bindiğiniz arabalar, paralar ve iç çamaşırları değilsiniz. Sizler, dünyanın şarkı söyleyip dans eden pisliklerisiniz". Doğrudan izleyiciyi hedef alan bu ifade, Schopenhauer ve Nietzsche arasındaki ayrımın zirve noktasıdır. Varlık'ı isteme olarak, insanı da bu varlığın bir parçası olarak düşünen Schopenhauer için, kişinin kendi olma uğraşı, istemenin gönüllü olarak hizmeti altına girme çabasıdır çünkü insanın özü, istemedir. Bu bakış açısı Schopenhauer felsefesinin ulaşmak istediği nihai noktanın, dışsal faktörlerle ilgili değil; bizzat Varlık'ın kendisiyle ilgili olduğunu açıklar. Diğer yandan istemeyi, gücü istemeyi kutsayan Nietzsche'de problem, kişinin kendi olmasının önündeki dışsal yapılardır. Tyler aracılığıyla Dövüş Kulübü'nün son sahnesine kadar belirlenen istikamet, kendi olmanın önündeki her engelin kaldırılmasına yöneliktir.

Bahsi geçen tartışma çerçevesinde, filmde verilmek istenen mesaja yönelik Schopenhauercı eleştiri, istemenin doyumsuzluğu ve ıstırabı çoğaltması bağlamında açığa çıkar. Nitekim gücü isteme, dövüş kulübünün dışına taşarak, anarşist bir boyuta ulaşır. "Er ya da geç, Tyler'ın istediği kıvama geliyorduk" söylemiyle Jack karakteri, güç arzusunun ulaştığı noktayı belirtir. Bu anlamda kulübe katılmak isteyen insanlar üzerinde kurulan iktidar, gücün kullanımına yönelik önemli bir göstergedir. Filmin ilerleyen bölümlerinde, dövüşlerin dozunun arttığı ve kıyamet projesi adı altında binaların ateşe verildiği sahnelere tanık oluruz. Jack, içindeki şiddeti baskın şekilde yaşamaya başlar. Eylemlerin dozunda yaşanan artış Jack'ın, Tyler'ın yanlış yaptığına ilişkin düşünceler geliştirmesine neden olur. Kulüp üyelerinden birinin ölümüyle sonuçlanan ve kıyamet projesi adı verilen dışa yönelik şiddet eğilimi, kulüp üyelerinin eylem sırasında ölen arkadaşlarına nesneymiş gibi davranması, Jack' in için değişimin başlangıcını ifade eder. Karakterin ağzından şu cümleleri duyarız; "Bu adamın bir adı var, nesne gibi davranmayın!" Filmin ikinci kırılma noktası da burada karşımıza çıkar. Merhamet duygusuna kapılarak, insanlara yalnızca birer nesne olarak baktı̆̆ının farkına varan Jack, Nietzsche'nin etkin nihilist, özgür insanından farklı bir yöne doğru ilerler. Jack'in söz konusu dönüşümü, Tyler' in ortadan kaybolmasıyla desteklenir. Ancak Jack, içinde bulunduğu durumdan gücü temsil eden Tyler sayesinde kurtulacağını düşünerek farklı şehirlerde Tyler'ı arar. Nitekim Tyler'ın kendi olduğundan habersizdir. Bu arayış neticesinde her şehirde bir 
dövüş kulübü olduğunu, Tyler'ın aslında kendi olduğunu anlamaya başlar. Jack, bir otel odasında Tylerle karşılaşır ve aynı kişi olduklarını idrak eder. Tyler'ın Jack'a söyledikleri önemlidir: "hayatını değiştirmek istedin, bunu kendin yapamıyordun. Olmak istediğin herşey oldu. Yani ben. Görünmek istediğin gibi görünüyor, senin istediğin gibi sevişiyorum. Zekiyim, yetenekliyim ve asıl önemlisi senin olmadığın kadar özgürüm”. Bu replik, yine Nietzsche'nin özgür insanının ağzından çıkmış gibidir. Gerçeği anlayan Jack, kıyamet projesi adı verilen, on iki büyük gökdeleni havaya uçurma planını durdurmak için elinden geleni yapar. Marla'yla buluşarak ona değer verdiğini söyler. Film boyunca Marla'yı yalnızca cinsel nesne olarak gören Tyler karakterinden oldukça uzak bir davranıştır bu. Jack, bir anlamda yaptıklarından pişman olur. Patlamaların olacağına yönelik endişesi nedeniyle Marlay'ı bölgeden uzaklaştırır ve karakola giderek tutuklanmayı talep eder. Jack'ın dönüşümü, Schopenhauer felsefesinde insan davranışlarını yönlendiren temel güdüler ${ }^{4}$ arasında, bencillikten sıyrılarak, merhamete yoğunlaşmanın ifadesidir bir bakıma. Oysa Nietzsche'nin özgür insanı, merhamet kavramını eşitleyici, sürü ahlakına yönelik bir kuruntu olarak niteler.

Tutuklanma talebi, memurlarının çoğunun dövüş kulübü üyesi olması nedeniyle kabul görmeyen Jack'1, bir başka sahnede patlayıcı dolu bir araçta, bombaları imha etmeye çalışırken görürüz. Kıyamet projesini sonlandırmak için bomba düzeneğini iptal etme çabasındaki Jack'ın yanında birden Tyler belirir ve Jack'ın yanılması için elinden geleni yapar. Jack, Tyler'ı silahla vurur ama kurşun Tyler'a işlemez. Schopenhauer felsefesinin bir başka öğesi, isteme yok edilemez, yalnızca reddedilebilir ki bu da belirli oranda mümkündür fikri (Safranski, 2015: 590-591), filmde böylece sunulmuş olur. Tyler ve Jack kavga ederler ve elbette güçlü olan Tyler, yani isteme, kazanan taraf olur.

Kıyamet projesini engelleme çabasıyla, Jack karakterinin kendini ele geçiren istemeye karşı savaşa giriştiğini söylemek mümkündür. Nitekim filmin sonlarında, açılış sahnesine dönülür. Tyler, bir gökdelenin üstünde, silahını Jack'a doğrultmuş ve patlayıcı yerleştirdiği on iki büyük gökdelenin yıkılışını izleme hazırlığı yapmaktadır. Tyler'ın bu sahnede söyledikleri Nietzsche'nin oluşun masumiyetine ${ }^{5}$ yönelik düşüncelerini dile getirir. "Az sonra herşey sıfırlanacak, tüm kredi kartları borçları yerle bir olacak". Jack, pencereden Marla'nın geldiğini görür ve Tyler'a vazgeçmesi için yalvarır. Ancak Tyler, tavrında kararlıdır ve hakim moral anlayışını simgeleyen finans tarihinin yıkımını izleyecek olmanın, sıfır noktasına dönmenin, bir anlamda deve-aslan-çocuk zincirinde (Nietzsche, 1967) son halkaya gelmenin keyfini sürer. Bu noktada Tyler'ın "Bunu ben yapmiyorum, biz yapıyoruz. Yani sen de sorumlusun. Beni sen yarattın, sorumluluğunu bil" cümlesi, Schopenhauer felsefesinde insanın eylemlerinde, sorumluluk sahibi olması gerektiğine yönelik bir gönderme olarak değerlendirilebilir.

Filmin son sahnelerindeki diyalog dikkat çekicidir. Tyler; "Seni hayal kırıklığına uğrattım mı? Benim sayemde nerden nerelere geldin. Bu işi tamamlayacağız. Her zaman ki gibi ben seni taşıyarak yola devam edeceğim ve sen bana teşekkür edeceksin”. Jack; "Bu kadarı çok fazla”. Tyler; "Sen artık anlamsızsın”. Bu diyalog, Nietzsche felsefesinde moraldan çıkmış ve geri dönülmeyen, kendine yabancı yeni bir yaratımın eşiğindeki özgür insanı ifade eder.

Jack, Tyler'ın elindeki silahın aslında kendi elinde olduğunu ve onu kullanmanın mümkün olduğunu düşünür. Bu sahne Schopenhauer'ın bilginin normalde istence hizmet

4 Schopenhauer'a göre insan davranışları bencillik, kötülük ve merhamet güdüsünden kaynaklanır (2014d: 83).

5 Nietzsche felsefesinde özgür olma erekleri, hedefleri reddetmek anlamına gelir. Birey elde ettiği özgürlükle, oluşun masumiyetini yaşama tekrar kazandırır. Bu aynı zamanda olumsallığın zorunluluğunu kabul etmek demektir (Pearson, 1998: 79). 
ettiğini, ama istencin bilginin hizmetine alınabileceği, bu yolla istençten uzaklaşılabileceği fikrine bir gönderme olarak da okunabilir. Jack silahı başına dayar ve Tyler'a şunları söyler “Tyler beni iyi dinle: Gözlerim açıldı” ve kendini vurur, Tyler ölür. Tyler'ın ölümü, bir anlamda Jack'in içindeki güç istencini yok etmesi anlamına gelir. Diğer yandan Tyler'ın ölümüyle Jack, Marla'ya "gerçekten düzeldim, inan bana her şey yoluna girecek" der. Patlamalar başlar ve Jack'la Marla' nın olduğu bina hariç diğer tüm binalar çöker. Jack Marla' ya “beni çok garip bir dönemimde tanıdın" der ve Marla'yla el ele tutuşurlar. Bu sahne, Tyler'ın Marla'yı cinsel obje olarak görmesinin aksine, Jack'ın ona değer verdiği, başka bir ifadeyle bir nesne gibi görmediği anlamına gelir. Schopenhauer' $1 n$ merhamet anlayışına, herkesin aynı acıyı yaşadığı, isteklerinin peşinde koştuğu fikrine paralel olarak, filmin başında kendisinin de hasta olmamasına rağmen, rahatlamak adına katıldığı terapi gruplarına katılan Jack'in, Marla'nın benzer amaçlarla, istencinin yönlendirmesiyle söz konusu gruplara katılmış olduğunu düşünmüş olma ihtimali, dikkate değerdir. Böylelikle, kendi dışındakilerle mesafeyi yok etme olarak tanımlanan Schopenhauerci merhamet kavramının filmde ele alındığı iddia edilebilir. Benzer şekilde, gökdelenlerin yıkılışını, güç isteminin sonlandığı, cinsel saldırganlığın durulduğu şeklinde yorumlamak mümkündür.

Diğer yandan Schopenhauer felsefesinde tek insanın özgürlügüu, bilginin yükselmesi ve birden bire istemenin hizmetinden çıkmasıyla mümkün olabilir. İsteklerin bitmediğini, her isteğin yerini diğerinin aldığını, istemelerin hedefsizliğini, boşluktan ve can sıkıntısından başka bir şey olmadığını gören kişi, kendi kendisini, kendi yapısını, sonuna kadar açık şekilde gören kişi, dünyaya sübjektif bakmaktan, herşeyi kendi beniyle ilgisi bakımından değerlendirmekten vazgeçer. Bu kişi kendi istemelerine, eğilimlerine ve kişi olarak ilgilerine 'hayır' diyecek kadar güçlü olmuştur. Böyle bir insan bağlarından koparak, dünyanın kendisi gibi ortada duran, aykırı insandır. Olup biten şey, kişinin temelden değişmesi, daha doğrusu karakterinin ortadan kalkması, kendi kişiliğinden sıyrılması 'yeniden doğmasıdır'. Böylelikle kişi, yeni bir insan olur ve insanları sever. Özgürlük, insanın yapısını görmesi ve görünce de kendini (istencini) silmesidir. Schopenhauer'ın kendini silme fikri, intihar değil, kişinin istencinden kurtulması anlamına gelir. Bu noktaya ulaşan kişi, karamsarlığa karşı nihilizmi kullanır. Böylelikle Schopenhauer'ın nihilizme yüklediği anlam da açığa çıkar. Filozofa göre nihilizm, kişinin kendinden yani istencinden sıyrılması anlamına gelir. Dolayısıyla Schopenhauer'in ideal insanı, kendi tabiatına karşı uzun zaman acı bir şekilde savaşarak onu yenen, kendisi ile diğerleri arasında sınırı kaldıran ulu insandır (Kuçuradi, 2013: 78-84). Literatürde yer aldığı şekliyle, karamsarlığının hakkını veren Schopenhauer, ulu insanda dahi, istemenin yok edilemeyeceği ve istemenin her yerde pusu kurup bekleyeceğini savunur. İfade edilen düşünce, Dionysoscu yaşama karşı, 'sanki gibi yaşama' felsefesidir. Bu fikir, ölmeyecek kadar yaşama ve isteme olarak da dile getirilebilir (Safranski, 2015: 590-592). Söz konusu bakış açısı, merhamet-sevgi boyutuna taşınan Jack-Marla ilişkisine açıklık getirdiği gibi, karamsar filozofun pusuda bekleyen istemesi, filmin yirmi beşinci karesinde görünen erkek cinsel organiyla, kendini gösterir. Başka bir deyişle Jack ve Marla özleri gereği, yaşam boyu sürecek bir tehdidin gölgesi altında varoluşlarını sürdüreceklerdir.

$\mathrm{Bu}$ noktadan hareketle, film boyunca izlediğimiz Jack'in yaşadığı değişimin, güç istemini kaybetmeyen Nietzsche' nin üst insanıyla değil; sanki gibi yaşayan ve merhamet-sevgi duygusunu ön planda tutarak acıyı asgari düzeye çekme gayretindeki Schopenhauer'ın ulu insanıyla noktalandığı söylenebilir. Başka bir ifadeyle Nietzsche' nin görüşleri doğrultusunda ilerleyen film, son sahnesiyle büyük bir paradoks yaratarak, Schopenhauerci bir son 
hazırlamıştır.

\section{Sonuç}

Şiddet, iktidar, tüketim gibi birçok alana temas eden ve çok farklı okumalara açık olan Dövüş Kulübü, İsteme ve nihilizm ilişkisini, Schopenhauer ve Nietzscheci bakış açısıyla ele alması bakımından da dikkat çeken bir yapıttır. Sıra dışı öyküsünün yanında, sinematografik öğelerin farklı kullanımlarıyla da beğeni toplayan ve sinema tarihinde önemli bir yer edinen film, anlatıcı rolünü de üstlenen Jack karakterinin yaşadığı değişimi konu edinir.

Karakter aracılığıyla tipik modern insan yaşamını betimleyen sahnelerle başlayan film, zaman ve mekânın belirsizliği bakımından, evrensel bir mesaj içerdiği izlenimi yaratır. Yoğun çalışma temposu ve muzdarip olduğu uykusuzluk nedeniyle yaşamını, kopyanın kopyası olarak niteleyen Jack' in tek isteği uykusuzluk problemine çözüm bulmak ve sıradan hayatında kişiliğini yansıttığını düşüncesiyle Ikea koltuk takımı, sandalye ve sehpaya sahip olmak gibi sıradan isteklerle yaşamını sürdürmektir. Bu betimlemeyle Jack karakterinin Schopenhauer'ın insan sınıflamasında en alt kategoride yer alan ve bilinçli değil; özü gereği isteyen fabrikasyon insanına karşılık geldiği söylenebilir. Benzer şekilde Jack, tanrı inancının yıkımıyla birlikte, kendi değerini yaratma şansını yakalamış ancak bunu fırsata çevirememiş, istenç hiçliğiyle nihilizm bataklığında sürüklenen Nietzsche'nin son insanına da örnek teşkil eder. İstemesini itaat ettiği modern dönem pratiklerine göre şekillendiren, başka bir ifadeyle istemeyen son insan, çevresine karşı ilgisiz ve bezgin tavırlarıyla dikkat çeken Jack ile benzerlik gösterir. Her iki düşünürün insan sınıflamasında alt kategoride yer alan Jack, içinde bulunduğu durumdan, rastlantı sonucu tanıştığı Tyler tarafından kurtulur. Alışılagelmiş tüm ahlaki değerleri hiçleyen, bedeninin dolayısıyla da tutkularının farkında olan Tyler, sahip olduğu özellikler bakımından Nietzsche'nin özgür insanını ve güç istemini simgeler. Varoluşunu bedeni üzerinden hisseden Tyler'ın yaşamından etkilenen Jack, zamanla Tyler gibi düşünmeye ve yaşamaya başlar. Nietzsche felsefesinde özgür insanı ifade eden Tyler, Schopenhauercı bakış açısıyla kendi dışında her şeyi hiçleyen ve tüm acının kaynağı olarak değerlendirilen istemeyi, bilinçli olarak isteyen akıllı insan kategorisinde yer alır. Nietzsche'nin son insan hakkındaki düşüncelerine benzer şekilde Schopenhauer, akıllı insanı en tehlikeli insan tipi olarak niteler. Çünkü bu insan tipi, kendisi dışındaki her canlıyı, amacına ulaşmada bir araç olarak görmesi bakımından insan eylemlerinin nedenleri arasında, fabrikasyon insana ait olan bencillikten çok, diğger bir eyleme geçme nedeni olan kötülükle ilişkilendirilir. Nitekim Tyler ve Jack, dövüş kulübünde gönüllü olarak bulunan insanların varoluş kanıtı olarak gördükleri acıyı ve şiddeti dışa yöneltirler. Eylemsel düzeyde yıkıcılığa tanık olduğumuz bu süreç, Nietzsche tarafından olumlanan etkin nihilist kişinin belirgin davranışlarını örneklendirirken, Schopenhauer'ın istemenin tatminsizliği ve giderilen her isteğin yerini başka bir istemenin alacağı fikriyle reddettiği bir yaşam şekline karşılık gelir.

Her iki düşünürün nihilizm ve insan özgürlüğü odaklı görüşleri göz önüne alındığında, filmin yönünü Nietzsche felsefesine çevirdiğini söylemek iddialı bir cümle olmayacaktır. Ancak kıyamet projesi adı verilen eylemlerde şiddetin dozunun artması, Jack'ın kurduğu ve içinde yer aldığı yapıyı sorgulamasına yol açar. Scopenhauer'ın, acıyı yok etmenin değilse de azaltmanın ön koşulu olarak gördüğü merhamet duygusunun ön plana çıktığı bu sahneyle birlikte, Jack karakterinin filmin başında kendi istemelerinin peşinde gitme kararıyla yaşanan dönüm noktasının ardından ikinci bir kırılma noktası yaşanır. Nietzsche felsefesinde 
ezginliğin belirtisi olarak ele alınan merhamet duygusu, filmde Jack'ın sorgulamaya başladığı süreçte Tyler'ın ortadan kayboluşuyla gösterilir. Jack, kontrolden çıkan olayların önüne geçebilmek için Tyler'ı aramaya koyulur ve bu arayış, kendisinin aslında Tyler olduğunu anlamasıyla noktalanır. Sözü edilen durum, şizofrenik bir vaka olmaktan çok, Nietzsche literatüründe her insanın güç istemine sahip olduğu, meselenin geleneksel değerlerden, deve olmaktan kurtularak, yerleşik ahlaki değerleri ve kurumları yıkmakta, aslana dönüşmekte olduğu fikrini doğurur. Bu yönlü bir bakış açısı, kıyamet projesinin de kendine ait olduğunu anlayan Jack için, çarpıcı bir sonuç ortaya koyar. Jack'in kendi olabilme hedefiyle başladığı serüven, film boyunca tanık olduğumuz şiddet görüntüleriyle daha fazla acıya, daha fazla 1stıraba neden olur. Kendi olmanın güç istemi ya da isteme olduğunun idrakiyle Jack, kıyamet projesini durdurmak için elinden geleni yapar. Dolayısıyla film, özgürlüğe ulaşma yolundaki Nietzscheci çözüm önerisini terk ederek, özgürlüğün pek de olası olmadığı, ancak istemeyi susturma oranında ona yaklaşılabildiğini öngören Schopenhauer felsefesine yönelir.

Jack'ın kıyamet projesini durdurma girişimleri sonuçsuz kalır ve geleneksel değerlerihakim morali simgeleyen finans binalarını havaya uçurmanın önüne geçmek için bombaları kendisi imha etmeye çalışır. Jack'ın, yaptıklarını sorgulama sürecinde görünmeyen Tyler, bu sahnede ortaya çıkar ve Jack'ı engellemek ister. Yıkımı isteyen Tyler, Jack'ın davranışından tatmin olmadığından, onunla kavgaya tutuşur. Jack'ın öldürmek için ateş ettiği Tyler, istemenin yok edilemeyeceği yönündeki Schopenhauer düşüncesine paralel olarak ölmez ve elbette gücün simgesi olarak kavganın galibi olur. Jack'ın öldürmek istediği aslında içindeki güç istemedir. Ancak istemesine öylesine tutsak olmuştur ki, onu istese de yok edemez.

Bu açıdan bakıldığında Dövüş Kulübü, Nietzsche felsefesinde edilgen nihilizmi terk ederek etken nihilizmi yaşayan özgür insan üzerinden ilerlese de, başkarakter Jack'ın, özgür insan özelliklerine karşı duruşuyla ve içindeki istenci simgeleyen Tyler karakterini öldürmesiyle izleyiciye, Schopenhauer felsefesine uygun bir son hazırlar. Tyler'sız kalan (güç isteminden kurtulan) Jack, Schopenhauer felsefesinde, ulu insan olarak tanimlanır. Schopenhauer'a göre özünde isteme olan insanın, kendine hayır demesi beraberinde acıyı getirir. Ama bu acı, insanları özgür yapan soylu bir acıdır. İstemeye hayır demek, acı çekmeye ve çektirmeye de hayır demektir. Kendi tabiatına karşı uzun zaman acı bir şekilde savaşarak onu yenen böyle bir insan, dünyanın parlak aynası olarak kalır. Onu artık hiç bir şey kaygılandırmaz, artık hiçbirşey sarsamaz. Çünkü bu kişi, bizi tutsak eden istekler, korku, kıskançlık ve öfke içinde savuran istemenin bin bir çeşit iplerini koparmıştır (Kuçuradi, 80). Ancak insan yine de temkinli, istemelere karşı savaşmaya hazır olmalıdır. Çünkü insanın bir bedeni olduğu sürece, isteme her an haklarını savunur ve bu hakları elde etmek için uygun anı, pusu kurup bekler. Nitekim Jack ve Marla'nın el ele tutuşup, gökdelenlerin yıkıldığı, güç istencinin üstesinden gelindiği sahnede, 25. kare olarak gösterilen erkek cinsel organı, istemenin en güçlü silahı cinsel dürtüye bir gönderme şeklinde yorumlanabilir.

Yürütülen tartışma ekseninde, filmde Nietzsche felsefesinden kopuşun en belirgin göstergesi, Jack'ın Tyler'ı öldürmesidir. Bu fikir, filozofun özgür insan tasarımının, nihai nokta olan üst insana geçişin son durağı olması göz ardı edilmeden ulaşılan bir sonuçtur. Zira, "Benim düşmanlarım yıkmak isteyenlerdir. Kendi kendilerini yaratmak isteyenler değil" (Akt, Camus, 2013:20), ifadesiyle özgür insanı, nihilizm içinde değerlendiren ve iyileşme sürecindeki bir hasta olarak niteleyen Nietzsche felsefesinin zirvesi, yıkmaktan kurtulan, başka bir ifadeyle değerleri reddetmenin ardından yeni değerler yaratan üst insandır. Ancak dikkat edilmesi 
gereken temel mesele, üst insanın güç isteminden vazgeçmeyişi; bilakis onun en temel özelliği olmasıdır. Söz konusu kavramın, kişinin yalnızca kendine yönelik değişimden söz ettiğine dair tartışmalar halen devam etmekle birlikte, tanımda geçen 'kurumları yıkmak' ibaresi, filmin Nietzsche felsefesinden kopuşuna yönelik düşünceyi güçlendirmektedir. Diğer yandan sevgi ve merhamet merkezli de olsa, Jack ve Marla'nın ilişkisi, filmin istemenin sonsuz olduğunu düşünen Schopenhauer felsefesiyle sonlandığını iddia etmek için yeterli bir argümandır.

\section{Kaynakça}

Akarsu, Bedia. (1979). Çağdaş Felsefe Akımları, İstanbul: Milli Eğitim Bakanlığı Yayınları.

Bryan, Magee, (2001). Büyük Filzoflar: Platondan Wittgenstein'a Batı Felsefesi. Çeviren: Ahmet Cevizci. İstanbul: Paradigma Yayınları.

Camus, Albert. (2013). Başkaldıran İnsan. Çeviren: Tahsin Yücel. İstanbul: Can Yayınları.

Copleston, Frederick. (1998). Nihilizm ve Materyalizm. (Çevire: Deniz Canefe). İstanbul: İdea Yayınevi.

Deleuze, Gilles (2010 ). Nietzsche ve Felsefe. Çeviren: Sertaç Canbolat. İstanbul: Norgunk Yayınları.

Deleuze, Gilles. (2001). Üstinsan: Diyalektiğe Karşı. Çeviren: Turhan Ilgaz. CogitoNietzsche: Kayıp Bir Kita. İstanbul: Yapı Kredi Yayınları.

Diken, Bülent. (2011). Nihilizm. Çeviren: Aylin Onacak. İstanbul: Ayrıntı Yayınları.

Dolson, Grace N (2009). "Schopenhauer'in Nietzsche Üzerine Etkisi". (Derleyen: Ahmet Aydoğan). Schopenhauer. İstanbul: Say Yayınları.

Folscheid, Dominique. (2015). Felsefe Akımları. (3. Bask1). Çeviren: Muna Cedden. Ankara: Dost Yayınevi. Kitaplığ1.

Heidegger, Martin. (2008). Varlık ve Zaman. Çeviren: Kaan H. Ökten. İstanbul: Agora

Kaufmann, Walter. (2009). İnsanı Anlamak II. (2.Baskı). Çeviren: Aziz Yardımlı. İstanbul: İdea Yayınevi.

Kuçuradi, Ioanna. (1967). Nietzsche ve İnsan. İstanbul: Yankı Yayınları.

Kuçuradi, Ioanna. (2013). Schopenhauer ve İnsan. (3. Baskı) Ankara: Türkiye Felsefe Kurumu Yayınları.

Nietzsche, Friedrich. (1964). Böyle Buyurdu Zerdüşt. Çeviren: A. Turan Oflazoğlu. İstanbul: Bilgi Yayınevi.

Nietzsche, Friedrich. (1997). Tan Kızıllı̆̆ı, (Çeviren: Hüseyin Salihoğlu-Ümit Özdağ). İmge Ankara: İmge Kitabevi.

Nietzsche, Friedrich. (2002). Güç İstenci. Çeviren: Sedat Umran. İstanbul: Birey Yayncılık.

Nietzsche, Friedrich. (2013). Ahlakın Soykütüğ̈̈̈ Üstüne. Çeviren: Ahmet İnam. İstanbul: Say Yayınları. 
Pearson, Keith-Ansell. (1998). Kusursuz Nihilist. (2. Bask1). Çeviren: Cem Soydemir. İstanbul: Ayrıntı Yayınları.

Safranski, Rüdiger. (2015). Schopenahuer Felsefenin Yaban Yılları. Çeviren: Ali Nalbant. İstanbul: Kabalc1 Yayınevi.

Salter, William M. (2009). "Schopenhauer, Felsefe ve Din”. Schopenhauer. (Derleyen:: Ahmet Aydoğan). İstanbul: Say Yayınları.

Sans, Edouard. (2006). Schopenhauer. Çeviren:Işıl Ergüden. Ankara: Dost Yayınevi.

Schopenhauer, Arthur. (2014a). İsteme ve Tasarım Olarak Dünya. (4. Baskı). Çeviren: Levent Özşar. İstanbul: Biblos Yayınları.

Schopenhauer, Arthur. (2014b). Hayatın Anlamı. (6. Baskı). Çeviren: Ahmet Aydoğan. İstanbul: Say Yayınları.

Schopenahuer, Arthur. (2014c). Aşk ve Cinnet. Çeviren: Kıvanç Kardeşler. Ankara: Yason Yayınları.

Schopenhauer, Arthur. (2014d). Merhamet. (3. Bask1). Çeviren: Zekai Kocatürk. İstanbul: Dergah Yayınları.

Schopenahuer, Arthur. (2018). Dünyanın Istırabı Üzerine. Çeviren: Ferhat Jak İçöz. İstanbul: Epsilon Yayınevi. 